\title{
POSTMODERN DÜNYADA GELENEĞiN YENIDEN INŞASI YA DA TiCARI BiR META OLARAK KEŞFi VE ÇAĞDAŞ TÜRK ROMANINDA GELENEK SORUNU
}

\section{Reconstruction or Invention of Tradition as a Commercial Meta in Postmodern World and Tradition Problem in Modern Turkish Novel \\ Dr. Fatih YALÇIN ${ }^{*}$}

ÖZ

Bu çalışmada modern dönemden postmodern döneme geçiş sürecinde geleneğin edebiyat dünyasında itibar kazanmasının sebepleri irdelenmeye ve bu değişim postmodernizmin felsefi ve sosyolojik temelleriyle ilişkilendirilmeye çalışılmıştır. $\mathrm{Bu}$ bağlamda modern ve postmodern dönemdeki gelenek algısı karşılaştırılarak farklılıklar ortaya konulmuş bu değişimin geleneğin yeniden inşası $\mathrm{ml}$ yoksa ticari bir meta olarak keşfi olarak mı değerlendirilmesi gerektiği sorusuna cevap aranmıştır. Çalışmanın sonunda ise çağdaş Türk romanından seçilen örnekler aracılığıyla geleneğin edebiyat metnine yansıtılış biçimi ve bu bağlamda yazarın özgürlük alanının sınırları sorgulanmıştır.

Anahtar Sözcükler: Postmodernizm, modernizm, gelenek, roman.

\section{ABSTRACT}

This study aims to examine the reasons of tradition's gaining repetition in the world of literature during the period of transition from modernism to postmodernism and this change, on the other hand, is tried to be associated to the philosophical and sociological basis of postmodernism. Concordantly, the differences are put forward by comparing the sense of tradition in modern and postmodern period and an answer is sought whether this change should be evaluated as reconstruction or invention of tradition as a commercial meta. In the end of the study, through the examples selected from Turkish novels, the way of tradition's reflection to a literary text and the limitations of author's realm of freedom are questioned.

Key Words: Postmodernism, modernism, tradition, novel.

Türk edebiyatında gelenek tartışması yenileşme dönemi Türk edebiyatının başlangıcıyla birlikte ortaya çıan ve günümüze kadar güncelliğini koruyan bir olgudur. Bu tartışma batılılaşma süreciyle ilgili olarak yapılan tartışmalarla paralel bir şekilde yürür. Batı karşısındaki yenilginin doğal bir sonucu olarak ortaya çıkan bu süreçte ve "aşırılıklar çağı" (Hobsbawm, 2006) olarak da nitelendirilen 20. yüzyılda yaşananlar bugün dahi birçok sosyal ve kültürel çatışmanın kaynağını besleyecek bir dinamizme sahiptir. Eskiyeni, geleneksel-modern gibi karşılaştırmalarla sürekli gündemde kalan bu tartışma toplumsal arada kalmışlığımızın en önemli göstergelerinden biri olarak ve hepsinden önemlisi kimlik oluşum sürecimizin en önemli problemi olarak varlığını korumaya devam etti.

*Bayburt Üniversitesi, Bayburt Eğitim Fakültesi, Türkçe Eğitimi Bölümü 
Temelde bir başkasının/ötekinin üstünlüğünün kabul edilmesiyle başlayan bu süreç bireysel ve toplumsal anlamda travmatik bir içeriğe sahipti. O güne kadar kendi üstünlüğünden hiçbir şekilde şüphe duymayan bir toplumun öteki karşısındaki yenilgisini kabullenmesi elbette ki kolay olmadı. Değişime direnenler karşısında, yenilginin bütün sorumluluğunu özel anlamda kimliğin, genel anlamda ise kültürün temel belirleyicileri olan geleneksel değerlere yıkan yenilikçiler saf tuttu. Siyah beyaz netliğindeki bu ayrışmanın oluşturduğu hengâmede ara renklerin, farklı bakış açılarının hayat bulması oldukça zordu ancak bu zorluğu göğüsleyebilen birkaç kişinin varlığıyla zaman zaman eski ile yeninin, geleneksel olanla modern olanın birlikte yaşadığı ve birbirinden güç alarak geliştiği ara dönemler yaşandı. Bu süreçte dikkatleri çeken bir diğer husus da bu kamplaşmanın dışında kalarak bakış açılarıyla ve eserleriyle bir denge kurmayı başarabilenler bugün en fazla hatırlananlar olmasıdır. Genel olarak bir yargıya varmak belki sakıncalı ancak edebiyat dünyası bugüne kalanlar bakımından irdelenirse ne tek başına eskinin ne de tek başına yeninin kalıcı izler bırakamadığını görebilmek mümkündür. Eskiden/gelenekten güç ve ilham alarak inşa edilen yeni zaman zaman kesintiye uğrasa da yoluna devam etmiş bugüne kadar varlığını korumuştur.

Modernite ve gelenek arasındaki ilişki iniş çıkışları ve içeriği bakımından gündemdeki yerini her dönem korumuştur. Hatta bazılarına göre modernite başlı başına gelenekle girişilmiş bir çatışmanın adıdır. Siyasal zeminde çok sert bir çizgi sürdüren modern gelenek çatışması, edebiyat sahasında daha hafif bir süreç takip etmiş, her şeye rağmen gelenek kendine bir yaşam alanı oluşturabilmiştir. Bu farklıı̆̆ın oluşmasında iki farklı alanın (siyaset-edebiyat) etki alanlarının ve gündelik olanla ilişkilerinin etkisi önemlidir. Kahraman'a göre siyasal modernite, kendisini meşrulaştırmak ve güçlük kılmak adına geleneksel olanı yok sayarak işe başlar. Bu amaçla da bellek sorununa özel bir önem atfeder. Geleneksel olanı silerek yeni bir bellek oluşturma siyasal modernitenin en önemli yöntemlerinden biridir. Bu süreçle ilgili bu tür genel kanaatlere ulaşmak mümkün gözükse de modernite, algısı ve uygulama biçimleri bakımından ciddi farklılıklar göstermiştir. Bu bağlamda başlangıç olarak Doğu ve Batı gibi çok da işlevsel olmayan ama kendi içinde kısmi tutarlılıklar taşıyan bir sınıflandırma yapılabilir. Elbette ki modernite Doğuda çok farklı bir biçimde algılanmış ve modern bir dünyanın inşası adına yapılanlar daha da özelleşerek bölgeden bölgeye farklılaşmıştır. Batı gibi modernleşme sürecini politik, dini, sosyal' değişim süreçleriyle birlikte yaşamış toplumlara göre bu alanlardaki değişimi yoğunlaştırılmış bir şekilde ve kısa bir sürede yaşamak zorunda bırakılmış toplumlarda modernite, travmatik sonuçlara -ki en önemlisi kimlik sorunudur- sebep olmuştur. Modern ve geleneksel olan arasındaki çatışmanın bir yansıması

'Batı modernleşmesi Fransız ihtilali, Aydınlanma, Reform ve Rönesans hareketlerinden bağımsız düşünülemez. Belki de bunların tamamını kapsayan bir süreçti. 
olan kimlik sorununun bugün bile aşılabildiğini söylemek mümkün değildir. Böyle bir farklılaşmanın doğal bir sonucu olarak estetik modernizmin bizim gibi toplumlar üzerindeki etkisi sert olmuş ciddi bir kamplaşmayla sonuçlanmıştır. Adını 1839 yılında ilan edilen Tanzimat Fermanından alan Tanzimat Dönemi Türk edebiyatından bugüne yayımlanan edebiyat dergilerinde yapılan eski-yeni tartışması ciddi bir yekûn tutar. ${ }^{2}$ Modernleşme dönemi Türk Edebiyatı içerisinde genellikle politik argümanlarla beslenen edebi hareketlerin kendini tanımlarken kullandıkları kavram haritasında gelenek öncelikli ve merkezi bir konuma sahiptir. Tanzimat Edebiyatı́yla başlayan bu çatışma Cumhuriyet dönemine kadar genel olarak söylem olarak sert bir tonda gerçekleşse de uygulamada gelenek baskın bir şekilde yaşamaya devam etmiştir. Ancak Cumhuriyet dönemiyle başlayan süreç geleneksel olana büyük bir darbe vurmuş, bu dönem niteliğine bakılmaksızın yeni olanın kutsandığı geleneksel olanın ise mahkûm edildiği bir dönem olmuştur. Yeni olanın itibar kazanmasında politik gücün desteği büyük oranda etkili olmuştur. Siyasi irade genel anlamda geleneksel olan her şeye karşı savaş açmış, eski/geleneksel olandan yana tavır almak ciddi bir bedel ödemeyi gerektirmiştir.

Gelenekle yeni arasındaki bu netameli süreç tam da yeni/modern olanın hâkimiyetiyle sonuçlanmak üzereyken, gelenek yeniden gündeme ge(tiri)lmiş bazılarına göre geleneğe iade-i itibar yapılmıştır. Bu değişim süreci sürekli olarak "postmodern" kavramıyla izah edilmeye çalışılmış ve birçok tartışmanın da önünü açmıştır. Geleneğe olan bu yöneliş sadece edebi sahayla sınırlı kalmamış resimden müziğe, müzikten sinemaya birçok sanat dalını kapsayacak yaygınlı̆ga ulaşmışıı. Burada bizi asıl ilgilendiren ve makalemizin asıl konusunu teşkil eden şey bu değişimin geleneğin yeniden inşası mı yoksa bir ticari meta olarak keşfi şeklinde mi okunması gerektiği sorusudur.

Giddens geleneği “belirli bir etkinlik ya da deneyimi, yinelenen toplumsal uygulamalarla yapılanmış olan geçmişin, bugünün ve geleceğin sürekliliği içine yerleştiren bir zaman ve uzam kullanma yolu olarak tanımlar" (Giddens 2004: 42) ve her yeni kuşağın devraldığı geleneği yeniden icat etmesi gerektiğini söyler. Doğal olarak geleneği bir dekor olarak kullanmak, çarpıtmak ve suistimal etmek yoluyla istikrarsızlaştırmak gelenek reddiyesinin farklı bir dil ve kapsamda devam ettirmekle eşdeğer bir tutumdur. Bu bağlamda edebiyatın gelenekle olan ilişkisini iki boyutta ele alabiliriz. ilki gelenekten yararlanma, ikincisi ise geleneği yeniden üretme. Postmodern dönemde kullanılan metinlerarasılık, pastij ve kolaj gibi teknikler aracılığıla gelenekle kurulan ilişki birinci boyutta değerlendirilebilir. Gelenekle olan ilişkide asıl önemli olan boyut ise Giddens'in ifadesiyle geleneğin yeniden icat edilmesidir.

${ }^{2}$ Saygıdeğer Hocam Erdoğan Erbay tarafından yapılan Eskiler Yeniler (Akademik Araştırmalar, Erzurum, 1997)adlı çalışma bu konudaki tartışmalarla ilgili önemli bir kaynak eserdir. 
Geleneğin son dönemdeki yükselişinin postmodernizmin düşünsel temelleriyle doğrudan ilişkili olduğu söylenebilir. Bu bağlamda postmodern düşüncenin gelenekle olan ilişkisini irdelemenin geleneğin son dönemdeki yükselişini anlamlandırmada bize katkı sağlayacă̆ı açıktır.

18. yüzyıl, aklı ve aklın yaratıcısı olan bilimi yaşamın odak noktasına alan Aydınlanma düşüncesinin yüzyılı ve modernitenin başlangıcı olmuştur. (Kızıler 2006: 49) Aydınlanma ve onun özellikleri ve ilerlemeci tarih anlayışının oluşturduğu bir dünya algısının kavramsal karşılı̆̆ı olan modernitenin en büyük iddiası insanoğlunun akıl ve bilim yardımıyla cenneti yeryüzüne indireceği iddiasıydı.(Şaylan2009: 35-36) Artık bilginin değeri araçsaldır. Bilgi, kendi kanunlarını içinde barındıran, doğayı çözümleyerek hayatlarımızı daha kesin ve daha rahat hale getiren şeydir.(West 2005: 36) İnsanoğlunun modernleşme sürecinin ortaya koyduğu birtakım kazanımları elde ettiği inkâr edilemese de, ürettiği yeni insan tipi ve bu insanın bugüne bıraktığı tarihsel miras ciddi bir eleştiriye tabi tutulmuştur. "ilerleme Çağı"nın gelecekle ilgili öngörüleri gerçekleşmemiş, sürekli ilerleme, daha kolay bir hayat ve daha çok mutluluk vaatleri bu sürece hizmet edenler ve genel anlamda tüm insanlık için tam bir hayal kırıklığıyla sonuçlanmıştır. Tanrı́nın ve aşkın değerlerin köleliğinden kurtulmakla özgürlüğüne kavuştuğunu iddia eden aydınlanma düşüncesi, insanoğlunu daha onur kırıcı bir köleliğe mahkûm etmiştir. İnsan artık kendi türünün seçkinlerinin ya da kendi yarattığı ve aşkın değerler yüklediği modern putların (para, statü, lüks vb.) kölesidir. Modernleşme sürecinin çocuğu olan "uygar insan" mutlu değildir.

Tarihsel süreç içerisinde ilkel zamanlardan modern zamanlara doğru sürekli daha özgür ve daha rahat bir hayat arayışının içerisinde olmuş olan insanoğlu, yapmış olduğu tercihlerle daha karmaşık bir hayatın üreticisi olmuş, telafisi olmayan hatalar yaparak içinden çıkılmaz, anlamsız, yabancı ve her geçen gün kendini biraz daha değersizleştiren bir düzene mahkûm olmuştur.

Yaşanan acılar ve hayal kırıklıklarının beslediği modernizm eleştirisi insanlığı yeni bir kavram olan postmodernizmle tanıştırmıştır. Modernleşmiş kültür hayatının ürettiği büyük anlatıların(meta-fiction) reddiyle başlayan postmodern süreç bu itirazın yükseldiği kültürel zemini oluşturur. Bazı düşünürlere göre modernin devamı olmaktan öte bir anlam ifade etmeyen bu dönem (Jameson 2005: 30) bazı düşünürlere göre ise tam anlamıla moderniteyle keskin bir farklılaşmayı ifade eder.

Dilek Doltaş’a göre posrmodernizm; "modernleşme sürecinin, insanlığı mahkûm ettiği telafisi mümkün olmayan kayıplara karşı sağduyunun ve kıyıda köşede örtük bir biçimde insanlığın vicdanında yaşamaya devam eden sahih değerlerin bir başkaldırısıdır."(2003: 24) Hayatı siyah ve beyaz netliğinde ve katılı̆̆ında algılayan ve modernizmi 
temel bakış açısını yansıtan düalist felsefenin çöküşü, beraberinde daha esnek ve renkli bir dünya algısının inşasının kültürel zeminini oluşturmuştur. Artık dünya, meta anlatıların belirlediği katı tanımlamaların dışında ara renk ve düşüncelerin sağladığı geniş bir çerçeveden izlenmekte ve tanımlanmaktadır. Bu bağlamda West'e göre postmodern düşüncenin soy kütüğü dört ayrı, fakat birbiriyle bağlantılı oluşum evresi geçirir. ilk olarak postmodernist düşünürler, Ortodoks aydınlanmanın bir yansıması olan doğa biliminin evrensel iddialarıyla, yine bu bilimsel anlayışın somutlaştırdı̆̆ı 'araçsal', 'nesnelleştirici' ya da 'indirgeyici' (zaman zaman da 'eril' ya da 'erkekçi') rasyonalizmini reddederler. Postmodern düşünürler, karşıt varsayımlara dayanan bir dünya algısına, yani dünyanın bilim ve teknolojiyi temel alarak dönüşmesine ve bu dönüşüme bağlı olarak oluşan ilerleme ideolojisine meydan okurlar. (Hobsbawm 2008: 697) Aksine Aydınlanma rasyonalizminin "uygarlaştıııı misyonu"nun elinde zor günler geçiren geleneklerden, kültürlerden, değerlerden ve halklardan söz etmeye başlarlar. (West 2005: 306) Bir anlamda modernizmin savaş açtı̆̆ gelenek, kültür ve değerlere iade-i itibar yapılmakta, modernizmin ötekileştirerek nesneleştirdiği her ne varsa bugünün öznesine dönüşmektedir.

Postmodernizmle birlikte geleneğin yeniden gündeme taşınmasının temel sebepleri postmodern söylemin içeriğinde aranmalıdır. Öncelikle modernizm karşıtlı̆ını tetikleyen temel unsur "ilerleme" idealinin insanlık için tam bir hayal kırıklığına sebep olmasıdır. İnsanlığın son yüzyılda yaşadığı acılar ve kapitalizmin aşkın bir değere dönüştürdüğü ve insanın aleyhine değer kattı̆̆ eşya karşısında insanın itibarsızlaşması ilerlemeye ve doğal olarak geleceğe olan inanca büyük bir darbe vurdu. Geleneğin/geçmişin reddi üzerine inşa edilen geleceğin itibar kaybetmesi geleneği, kaybedilmiş değerleri ve kültürü yeniden gündeme getirdi. Boym’a göre “sanayileşmenin ve modernleşmenin hızlı temposu insanların geçmişin yavaş ritimlerine, sürekliliğe, toplumsal kaynaşmışliğa ve geleneğe duydukları özlemi daha da yoğunlaştırdı. (Svetlana 2009:45) Bir anlamda insanoğlu, geleceğin belirsizliğinin verdiği huzursuzluktan geçmişin/geleneğin bilinen ve alışıın olduğu dünyasına sığınarak kurtulmaya çalışmaktadır. Gerçekliğin hiper gerçekliğe dönüştüğü bir çağda geçmiş duyumu yitirilmiş, her şey bitimsiz bir şimdiki zamana dönüştürülmüştür. Hobsbawm'a göre "geçmişin imha edilmesi, 20. yüzyll sonunun en karakteristik ve en ürkünç fenomenlerinden biri. Genç erkek ve kadınların çoğu, içinde yaşadıkları zamanın kamusal geçmişiyle hiçbir organik bağ olamayan bir tür sürekli şimdide yetişmektedir."(Kızıler 2006: 141-142) "Geçmişe takılma, anı yaşa" şeklinde formüle edilebilecek olan bu tutum beraberinde karşıtını üretmiş, bellek yitimine uğramış postmodern toplumda geçmişe duyulan özlem baskın bir duygu haline gelmiştir. Bugünün kompleks değerler silsilesinden kimlik devşiremeyen insanın köklerine dönüşünü sembolize eden bu sürecin izlerini politikadan, sanata birçok alanda bulmak mümkündür. 
Sanatsal açıdan geleneğe olan ilginin bir başka gerekçesi olan metinlerarasılık kavramı da postmodern süreçle bağlantılı bir kavramdır. Metinlerarasılık kavramının ilk defa, Julia Kristeva tarafından 1967 yılındaki bir makalesinde kullanılmıştır. Buradaki kullanımla birlikte Bahtin'in "Diyalogsallı" kuramı "metinlerarasılık" olarak Kristeva tarafından Batı eleştirisine kazandırılmış olur. Kristeva'ya göre, "Her metin alıntılamalardan oluşma bir mozaiktir. Her metin bir başka metinden oluşma onun transformasyona uğramasıdır. (Ekiz 2007:124) Yeryüzünde söylenmemiş söz kalmamıştır ön kabulünden hareketle ulaşılan bu yargı beraberinde geleneksel metinlerin yeniden gözden geçirilmesine, çağdaş metinlerde bu metinlerle ilişki kurulmasına sebep olmuştur. Bu geriye dönüş sadece metin düzeyinde olmamış genel anlamda tarihe olan ilgi de artmıştır. Bu dönemde tarihi romanların yaygın hale gelmesi böyle bir sürecin sonucu olarak değerlendirilmelidir. Yine tiyatro ve sinemada da aynı süreç yaşanmış gelecek kadar geçmiş de bu iki sanat dalının ilgisini yoğun bir şekilde çekmiştir. Hilmi Yavuz'a göre metinlerarası ilişkinin, özellikle gelenekle ilişki kurmak ve geleneği yeniden üretmek bağlamında da değerlendirilmesi gerekiyor. (http://arsiv.zaman.com.tr/2002/05/01/yazarlar/hilmiyavuz.htm)

Postmodernizmin bir diğer belirgin özelliği de "çoğulculuktur". Modernizmin tek tipleştiren bakış açısına karşı postmodernizm çoğulcu yapıyı benimser. İnsanları, idealize edilmiş bir "tek tip"e benzetmeye çalışmak yerine farklılıklarıyla birlikte kabul etmeyi benimseyen bu bakış açısı, modern dönemde reddedilen, unutturulmaya çalışılan, ötekileştirilen ne kadar değer varsa gündeme taşımış "geleneksel olana” kapı aralamıştır. Öyle ki geçmişte ortak aidiyetler üzerinden yapılan kimlik tanımlamaları yerine farklılıkların abartılı bir şekilde önplana çıkarıldığı, amaçlı bir şekilde görünür kılındığı ve kimlik tanımlamalarının merkezine oturtulduğu bir döneme geçiş yapıldı.

Bu bağlamda irdelenmesi gereken bir diğer konu da modernizmin en belirgin özelliklerinden biri olan ve bir toplumu veya tarihi özselci, indirgeyici ve genelleyici kuramsal ilkeler çerçevesinde açıklamaya çalışan meta-anlatılara postmodernizmin yaptığı reddiyedir. Kuşatıcılık yerine parçalılığı benimseyen postmodern düşünce modernizmin indirgeyici ve genelleyici tavrına karşı çıkmış farklılıkların bu genelleyici potada eritilmesinin yanlışlığına vurgu yapmıştır. Doğal olarak sürekli ilerleme ideali merkeze alınarak yapılan tek tipleştirici gelecek kurgularının yerine farklılıkları önceleyen bir bakış açısı hâkim kılınmaya çalışılmıştır. Sonuç olarak bu bakış açısı da farklılıkların tarihsel kaynağı olan gelenekleri gündeme taşımıştır.

Postmodern düşünce seçkinci değil popülisttir. Doğal olarak bütün toplum kesimlerine ulaşmak gibi bir amacı meşru görür. Hâlbuki seçkinci sanat anlayışında önemli olan nitelikli bir kitleye ulaşmak ve sadece onların zevklerine hitap etmektir. Genel anlamda sanatın ve özel anlamda edebiyatın gelenekle kurduğu ilişki onu daha popüler yapmış, 
ona çok geniş bir kitleye hitap etmenin yolunu açmıştır. Bu bağlamda modern sosyolojinin merkez-çevre tanımlamalarındaki kesinliğinin ortadan kalkmasının, merkezle çevre arasında sınırların çevre lehine esneklik kazanmasının geleneğin yükselişinde önemli bir etkisi vardır. Çevrenin kimlik tanımlamasının en önemli kaynaklarından biri olan geleneğin çevrenin merkeze doğru genişlemesi ve yükselmesinden etkilenmesi kaçınılmaz olmuştur.

Geleneğin yeniden gündeme gelmesi sözkonusu olduğunda irdelenmesi gereken bir diğer kavram da "nostalji”dir. Stauth ve Turner'a göre insanların kendi sınırlılıklarının ve sonluluklarının bilincinde olmalarından kaynaklanan yabancılaşmayı dışa vuran ontolojik bir nostalji sorununun bulunduğu öne sürülebilir. (Stauth, Turner 1998) Doğal olarak modern dünyadan umduğunu bulamayan insanlarda nostaljiye yönelişin artması kaçınılmaz bir süreç olmuştur. Stauth ve Turner nostaljik paradigmanın dört temel bileşkesinin olduğunu iddia eder. Bunlardan ilki insanların belli bir yer ve yurda sahip olduğu altın bir çağdan ayrilış nosyonunu da içeren tarihin bir sapma ve düşme olarak görülmesidir. Bir anlamda insanın Tanrı'dan uzaklaşması anlamına gelen bu durum, geçmişten bugüne insanoğlunun düşüşünü, ilahi varlıkla başlangıçtaki birliğini yitirdiğinin farkına varmasını yansıtır. (Pappenheim 2002: 101) Modern dönemde yersiz yurtsuzlaşmaya bir tepki olarak da düşünülebilecek bu bakış açısının tarihsel kökleri asıl yurt olan "cennetten kovulma"ya kadar götürülebilir. Yine İslam dünyasında ideal bir hayat dönemi olarak anılan "asrı-1 saadet" dönemine dönüş özlemi de bu kapsamda değerlendirilebilir. ${ }^{3}$ Nostaljinin ikinci temel bileşkesi ise modern toplumsal sistemlerin ve bunların barındırdıkları kültürün, doğası gereği çoğulcu, laik ve çeşitli olduğu düşüncesidir. Bu çoğulluk inanç ve pratiğin keskin bir şekilde farklılaşmasına sebep olur. Üçüncüsü ise özerk bireyin modern bir devletin tahakkümü altında bürokratik düzenlemeler dünyasında kapana kısılması nedeniyle bireyliğin ve bireysel özerkliğin yitip gittiği düşüncesidir. Bu bağlamda aksi yönde bireyselliğin artması sebebiyle toplumsal ilişkilerin zayıfladığı, insanların birbirine karşı duyarsızlaştı̆̆ düşüncesinin de özellikle doğu toplumlarında nostaljinin temel bileşkelerinden biri olarak görülmesi gerekir. Modern toplumlarda bireyler birbirlerinden o kadar ayrı ve tecrit edilmişlerdir ki sadece birbirlerini belirli amaçlara yönelik araçlar olarak kullanabildikleri zaman temas kurmaktadırlar. (Pappenheim 2002: 72) Son olarak ise yalınlı̆̆ın, sahiciliğin ve kendiliğindenliğin yitirilmesi düşüncesi Stauth ve Turner'a göre nostaljinin dördüncü bileşkesini oluşturur. (Stauth, Turner, 1998: 262, 263) Bu dört temel bileşkenin ortak noktası bütün bu süreçler neticesinde insanın giderek değersizleştiğine olan inançtır. Bugün mutlu değilseniz ve gele-

\footnotetext{
${ }^{3}$ Son dönemde Türk edebiyatında asr-1 saadet döneminde yaşamış kişilerin hayatlarına yönelik Sibel Eraslan'ın Can Parçası: Hz. Fatıma, Siret-i Meryem, Çöl/Deniz Hz. Hatice gibi biyoğrafiromanları bu kapsamda değerlendirilebilir.
} 
cekten ümidiniz yoksa geçmiş sizin için daha değerli hale gelir ve bir anlamda bir sığınağa dönüşür.

Geleneğin yeniden gündeme gelmesinin düşünsel temelleri ne olursa olsun çalş̧̧mamızda asıl irdeleyeceğimiz konu çağdaş edebiyata geleneğin, kültürün ve değerlerin yansıma biçimi üzerine olacaktır. Bu süreç "geleneğin yeniden inşası" gibi pozitif bir algı oluşturacak şekilde kavramlaştırılmaya çalışılsa da uygulamada ciddi tartışmalara sebep olmaktadır. Bazılarına göre bu süreç içerisinde gelenek kullanılmakta, deformasyona uğramaktadır. Özellikle edebi türlerde geleneğin yansıtılıș biçimi bir takım çevrelerde rahatsızlık oluşturmakta, bu tür eserler "gerçeğe sadakat" fikri çerçevesinde ciddi bir eleştiriye tabi tutulmaktadır. Bu tür eleştiriler karşısında yapılan temel savunma ise sanat eserlerinin kurgusallığını öne çıkaran bir görüntü arzetmektedir. Sanatçının kurgusal bir eser ortaya koyduğu ve bu konudaki özgürlüğünün asla tartışmaya açı olmadığı savunması bu tartışmanın da nirengi noktasını oluşturmaktadır. Sanatçının/yazarın özgürlügünün bir sınırı var mıdır ya da olmalı mıdır sorusuna vereceğiniz cevap bu konudaki bakış açınızı açık bir şekilde ortaya koyacaktır.

Linda Hutcheon, "Postmodernizmin Poetikası: Tarih, Teori, Kurgu" adlı eserinde postmodernizmi "çelişkili bir girișim" olarak tanımlar. Postmodernizmin sanat biçimleri geçmişin sanatının eleştirel ya da ironik yeniden okumalarla geleneği kullandığını ve suistimal ettiğini, yerleștirip ve sonra da istikrarsızlaştırdığını iddia eder. (1998: 23, Öğretir 2009: 50) Kullanmak, suistimal etmek ve istikrarsızlaştırmak kelimeleri etrafında geleneğin ve dolaylı olarak tarihin yeniden gündeme gelişi irdelendiğinde bunun geriye dönüşün doğal bir süreç olmadı̆̆ı, piyasa şartlarını gözettiği ve bir anlamda geleneği/geçmişi ticari bir metaa dönüştürdüğü gerçeğiyle yüzleşmek zorunda kalırı.

Türk edebiyatı içerisinde oluşan edebi hareketlerin neredeyse tamamı ya geleneği reddederek, ya dönüştürerek ya da olduğu gibi yaşatmaya çalışarak bir şekilde kendini gelenekle ilişkili olarak tanımlama gayreti içerisine girmiş hiçbir dönemde gelenekten bağımsız olamamıştır. Bugün de çevrenin merkeze, merkezin çevreye doğru kayması gibi sınırların esnekleștiği bir dönemde yeni toplumsal yapıyla ilişki kurmada sorun yașayan aydın-sanatçı bu ilișkiyi kolay bir șekilde kurmalarını sağlayacak geleneği ortadan kaldırdıkları için lümpen kültüre sığınmak zorunda kalmıştır. Lümpen kültürün, geleneği yozlaştıran etkisini güçlendiren bu tavır aydın-sanatçının toplumda oluşan kültürel boșluğu dolduracak birikime, kültürel geleneğe sahip olmamasından, söyleyecek sözü ve toplumu da yönlendirmek istediği bir hedefi bulunmamasından kaynaklanmıştır. (Kahraman 2008: 86) Lümpen kültür ne geleneği ne de modern olanı kuşatabilecek bir kuşatıcılı̆ga sahip değildir. Bir anlamda bu ikisi arasında oluşan "ara kültürü" temsil eder. 
Hasan Bülent Kahraman geleneğin/geçmişin Türk edebiyatındaki yükselişinin doğal bir süreç olarak değil bir etkilenme ve yabancılaşma sorunu olarak görür. Ona göre bu durum Türk yazar-sanatçılarının Güney Amerika edebiyatını özellikle Borges'i taklit etmelerinden kaynaklanmıştır ve özgünlükten yoksundur:

"ilgi alanımız içine birdenbire kentler girdi, kentlerin boğuntulu sokakları, mahalleri girdi, keşişler, simyacılar, Ortaçağ'da yazılmış yapıtlar, dinsel kitaplar, bunların anlaşılmayan arkaik dilleri girdi. Artık öykü yazmaz olduk, metin üretmeye başladık. Artık öte dilleri aramaya koyulduk. Çapraz-satranç metinler gelişstirdik. Ve nihayet artık kendimize ait kavramları ve değerleri artık tıpkı bir yabancıymışız gibi "dışardan" gözlemler olduk". (Kahraman 2008: 88-89)

Bu değişimi "kendine dışarıdan bakmak" şeklinde tanımlayan Kahraman'a göre bu bizim için yeni bir durum değildir. "Parnas okulunun ikinci sınıf şairlerini öykünen sembolistlerden ikinci Yeni'ye ve Güney Amerika edebiyatı aktarmacıllğına kadar geçen zamanda aydın bilinçlenmemiş, kendisine özgü değerleri özümseyememiş, ayaklarını hala yere basamamıştır."(2008: 89) Kahraman'ın "kendine dışarıdan bakmak" diye tanımladığı bu durum Hilmi Yavuz'un da gündemindedir. Yavuz'un yerli oryantalizm diye kavramlaştırdığı bu durum Doğu(lu)nun kendine Batı $\left(l_{1}\right)$ nın gözüyle bakmasını ifade eder. Tanzimattan bugüne Türkiye'nin anti-oryantalist soykütüğünü çıaran Yavuz, bu çerçevede Ahmet Mithat, Namık Kemal ve Filibeli Ahmet Hilmi'yi oryantalizme karşı vermiş oldukları mücadele nedeniyle ${ }^{4}$ takdir ederken Cumhuriyet dönemi aydınyazarlarına göndermede bulunur:

“Şşte bir anti-oryantalist soy kütügüü! Tanzimat'tan II. Meşrutiyet'e, oradan da Cumhuriyet'e eklemlenen bu 'aydın' soy kütügünde, ne yazık ki, Cumhuriyet aydınları yok! Çünkü Namık Kemal'lerimiz, Ahmet Mithat Efendi'lerimiz, Şehbenderzade'lerimiz yok da ondan! Artık bizim de yerli Renan'larımız, yerli Draper'lerimiz, yerli Dozy'lerimiz var. Zihinlerini oryantalizme, kayıtsız koşulsuz teslim etmiş aydınlar! (http://arsiv.zaman.com.tr//2001/06/01/yazarlar/HilmiYAVUZ.htm) (02. 07. 2012)

Kahraman, son dönemdeki edebiyat-gelenek ilişkisini fanteziyle ilişkilendirerek edebiyatın özünde bir soyutlama olduğunu ve doğal olarak içinde düşsellik ve fantezi boyutu içereceğini söyler ve şu soruyu sorar: "Tekrar edeyim, labirentler, simyacılar, keşişler, kentler, şunlar vardır da, son yıllarda verilmiş hangi yapıtımızda etiyle kemiğiyle bizim

\footnotetext{
${ }^{4}$ Yavuz, bu yazısında Ahmet Mithat'ın W J Draper adında Amerikalı bir bilim adamının 1874'te yayımlanan Conflict Between Religion and Sciens başlıklı kitabına cevap olarak yazdı̆̆ı Niza-ı ilm ü Din, Namık Kemal'in Ernest Renan'ın 1883'te Sorbonne Üniversitesi'nde verdiği bir konferansa cevap niteliği taşıyan Renan Müdafaanamesine, Filibeli Ahmet Hilmi'nin ise Reinhardt Dozy'e yönelik bir reddiye olan Tarih-i ìslamiyet'e göndermede bulunur.
} 
insanımızın bulunduğu görülür? Ve o fantazyalar, o düşler, o sanrılar nereye ulaşmak için yazılmıştır? Yaratılmıştır?"(Kahraman 2008:94) Burada söz konusu olan geleneğin ve geçmişin araçsallaştırılması, Hutcheon'un dediği gibi kullanılması, suistimal edilmesi ve istikrarsızlaștırılmasıdır. Hilmi Yavuz'un Orhan Pamukla ilgili olarak Osmanlı ve isslam geleneklerini bir 'decorum' olarak kullandığı iddiası (http://www.zaman.com.tr/yazar.do?yazino=444653\&keyfield=6F7279616E74616C697A6 D) (03. 07. 2012) da Hutcheon'un iddiasıyla örtüşür. Kahramanın da dediği gibi ortada etiyle kemiğiyle bizim insanımız yoktur.

Buna benzer bir itiraz da Dücane Cündioğlu'ndan Elif Şafak'ın aşk romanına yönelik olarak gelir. Cündioğlu, "kurgu" sihirli sözcüğünün arkasına sığınarak birtakım yazarların özgür ve yaratıcı muhayyilesine kimsenin karışamayacağını iddia ettiklerini ancak yazdıklarıyla hakikati de sanatı da incittiklerini iddia eder ve tarihî isimlerin bir kukla gibi kullanılmasına karşı çıkar:

"Hz. Pir-i Mevlâna, oğulları Sultan Veled ile Alâeddin, ikinci eşi Kerra Hatun, ve divânesi Şems-i Tebrizî ve kllıktan kılı̆ga sokulan zavallı eşi Kimya Hatun...

Romancılarımızın hepsinin de ucundan kenarından, kendilerince ve fakat farklı nisbetlerde kuklalaştırdıkları ortak kahramanlar iște bu birkaç tarihî isim. Ne rol verilmișse kendilerine, onu oynamak zorunda kalmışlar. Yazarların özgür muhayyileleri, iplerini ne tarafa çekmeyi dilemişse, kuklalar da çaresiz o yöne meyletmişler." (http://yenisafak.com.tr/yazarlar/?t=29.08.2009\&y=DucaneCundioglu) (02. 07. 2012)

Cündioğlu'nun itirazıyla gündeme gelen asıl konu tarihi kişiliklerin kurgusal metinlere taşınırken yazar/sanatçının ne kadar özgür olduğu konusudur. Ortada yaşanmış bir gerçeklik söz konusu iken bu gerçekliğin kurguya kurban edilmesini bir yazar/sanatçının özgürlük sınırları içinde düşünmek sorunlu bir yaklaşım olacaktır. Kurgusal metinlerde her yazar kendi kahramanın yaratmakta özgürdür ancak tarihî kişiliklerin gerçeklikten uzaklaşılarak özellikle piyasa şartlarının da dayatmasıyla bir roman kahramanına dönüştürülmesi sürecinde gerçeğe sadakat yazar/sanatçı özgürlüğüne feda edilemeyecek kadar önemli bir konudur. Bu tarihin/geleneğin kullanılması, suistimal edilmesi ve bazen de istikrarsızlaştırılması anlamına gelir ki asıl itiraz edilmesi gereken konu da budur. Yaşanmış bir hayatın yeniden kurgulanması bir özgürlük alanı değildir, olmamalıdır. Eğer gerçek tahrif ve suistimal ediliyorsa bunu kim hangi amaçla yapıyorsa yapsın bu tahrif ve suistimal edilen tarihî gerçekliğe veya kişiye karşı işlenmiş büyük bir suçtur.

Postmodern düşüncenin temel özelliklerinden biri olan çoğulculuk fikrinin bir yansıması olarak "öteki”nin sesini duyurmak, onu daha görünür kılmak adına tarihi ve gelenekleri gerçeği yansıtmayacak şekilde abartarak hedef tahtasına koymak, suistimal etmek tartışııması gereken bir diğer konudur. Baba ve Piç'i ensest ilişkiler üzerine kurgulayan Elif Şafak, Pinhan'da tekkelere eşcinselliği sokar. Asıl sorun bu tür ilişkilerin tekkelerde 
yaygın olarak bulunan ilişkilermiş gibi genelleştirici bir tavırla anlatılmasıdır. Yine Orhan Pamuk'un "Benim Adım Kırmızı" romanında sanatçılar arasındaki "oğlancılık" temayülü de aynı genelleştirici tavırla anlatılır. Son dönemde çekilen tarihi sinema filmlerinde de aynı tavırla karşılaşırız. Yazarların bu bakış açısıyla Osmanlı sarayını haremden, haremi ise cinsellikten ibaret bir yapıymış gibi anlatan, resmeden oryantalist bakış birbiriyle örtüşür. Yavuz'a göre bu tür yazarlar klasik oryantalist imajı yeniden üreterek Batı́nın dikkatini çekme gayreti içerisindedir:

"Haremler, hamamlar, gizemli Doğu, peçeler, vs. bütün bunlar arkasındaki gizem. Şimdi bu gizemi bugünkü Istanbul kenti yaşamına atfetmek ne kertede sahih bir Türkiye imajı verir. Bunu sorgulamak gerekiyor. Ama böyle bir imaj Istanbul'a yapıştırıldığında, istanbul'a atfedildiğinde Boğaz'a, Galata'ya, Galata'nın yer altı mahzenlerine böylesine bir esrarengizlik atfedildiğinde bu, tabii ister istemez Batıl' nnn zihninde eski geleneksel oryantalist imajla bütünleşen bir istanbul ya da Türkiye kavramı yaratıyor." (Armağan 2003: 14)

Yukarıda da ifade edildiği gibi bu tavır "kendine dışarıdan bakmak"la, kendi insanımızı öteki diye konumlandırmakla (Armağan 2003: 13) ilgili bir durumdur. Bir sanatçı/yazar için dışarıdan bakabilme yeteneği genel olarak nesnellik kazandıran bir etkiye sahiptir. Ancak bu bakış, belirtilen örneklerde olduğu gibi mesafe iyi ayarlanmaz ise kendine, kendi toplumuna yabancılaştıran bir konuma doğru sürüklenme tehlikesini de içinde barındırır.

Yeni tarihselcilik bağlamında tarihin metinselliğine yapılan vurgu, tarihi zaman zaman bir fantezi alanına dönüştürmüş, bugünün değerleriyle okura ulaşmakta zorluk çeken yazar/şair için tarih kurgulanabilir popüler bir nesneye dönüşmüştür. Nesnel bir tarih anlayışının olamayacağı temel iddiasını dillendiren bu bakış açısı tarihin ancak metinler üzerinden takip edilebileceğini ve dolayısıla da hiçbir metnin tamamıyla nesnel olamayacağı ön kabulüyle tarihî metinler üzerindeki yazar-çevre-zaman etkisine dikkati çeker. Ancak bu bakış açısı bile "metni" merkeze aldığı için tarihe sınırlı bir kurgusallık atfeder. Doğal olarak bir yazarın önceki kaynak metinlerden tamamen bağımsız bir kurgusallığı meşru görmesi mümkün olamaz.

Hayden White'a göre tarihsel olayların öyküleştirilmesi belli bir biçim (şiir/öykü/roman, vb.) içinde yazılmalarını ve yazar/tarihçi açısından öznel bir seçimi zorunlu kılar. Neyin geri planda bırakılıp neyin daha görünür kılınacağı gibi tercihler metnin nesnelliğine doğal olarak zarar verecektir. (Oppermann 2006: 14) Ancak tüm bu öznel müdahalelerin tarihsel gerçekliği saptıracak ve bütünlüğü bozacak boyutlara ulaşmaması gerekir. 
Özellikle bu tür metinlerin muhatabı olan okur kitlenin niteliği göz önüne alındığında her ne kadar yazarlar metnin kurgusallığına atıfta bulunsa da gerçekte okur tarafından öyle algılanmadığı, bu tür metinlerin tarihsel bir bilgi kaynağı olarak değerlendirildiği gerçeği ile karşı karşıya kalırız. Bir taraftan nitelikli okur arayışıı dillendiren edebiyat dünyasında popüler edebiyatın bu derece yaygınlık kazanması başlı başına bir tutarsızlıktır. Popüler bir dünyada nitelik arayışının anlamsızlı̆ı kadar geniş bir kitleye hitap etme gayretinin yanında nitelikli okur arayışı da anlamsızdır. Özellikle son dönemde üretilen tarihsel metinler üzerinde çıkan tartışmalar dikkate alındığında görülecektir ki bu tür metinler tarihsel belgeler gibi okunmakta, aslında tarih insanların zihninde yeniden yazılmaktadır.

Tarihsel bilginin nesnelliğinin bile tartışıldığı bir dönemde bir de yazarların tarihî metinler üzerinde kurgu yapma özgürlügü ortaya çıkınca tarih bir fantezi alanına dönüşmüştür. Hiçbir etik kaygı taşımayan bu tavır zaman zaman tarihin ideolojik kaygılarla çarpıtılmasına, kişilik haklarının ihlaline kadar ileri boyutlara varabilmektedir. Bu tür metinleri kurgusal metinler olarak değerlendir(e)meyen okur zihninde tarih bu yolla suistimal edilmekte, istikrarsızlaştırılmaktadır. Böylece, toplumsal aidiyetin önemli belirleyicilerinden biri olan ortak tarih şuuru adım adım ortadan kaldırılmaktadır. Uzunca bir süredir reddedilerek yok edilmeye çalışlan tarihsel miras şimdi bizzat gündeme taşınarak tahrip edilmeye çalışılmaktadır. Somut tarihsel mirasın korunması üzerine projeler üreten ve bu mirasa zarar verecek uygulamaları şiddetle cezalandıran ulusal ve uluslar arası kuruluşların somut olmayan tarihsel mirasın korunması konusunda hiçbir adım atmaması düşündürücüdür. Bir taraftan somut tarihsel miras korunurken ve her yerde aslına sadık kalmak ön şartıyla restore edilirken somut olmayan tarihsel mirasın kurgusal fantezilere kurban edilmesi kabul edilebilir bir durum değildir.

Sonuç olarak bu tür eserlerde tarih ve gelenek sadece bir dekor vazifesi görmekte, bașka bir ifadeyle kullanılmaktadır. Hepsinden önemlisi ise suistimal edilerek geleneğe karşı negatif bir algının oluşmasına sebep olunmaktadır. Böyle bir durumda geleneğin yeniden inşası gibi bir kavramlaştırmanın genel olarak modern sanatın gelenekle olan ilişkisini tanımlayabilecek bir kavramlaştırma olmadığı açık bir şekilde görülmektedir.

Edebiyatın gelenekle olan ilişkisi bağlamında yukarıda belirtilen iki boyut dikkate alındığında son dönemde Türk edebiyatında gelenekle kurulan ilişkinin ancak gelenekten yararlanma boyutunda değerlendirilebileceği açıktır. ikinci boyuta yani geleneğin yeniden inşasına yönelik çalışmalar ise sınırlı sayıdadır. Çünkü geleneğin yeniden inşası gelenekten beslenerek geleneği aşmak gibi zor bir sürecin neticesinde ancak gerçekleşebilir. Fakat modern çağın edebiyatı olarak da tanımlayabileceğimiz popüler kültürden beslenen edebiyat böyle zor bir süreç göze alınamadığı için bu kadar yaygındır ve popü- 
ler edebiyatın gelenekle ilişkisi ya yoktur ya da ancak ondan yararlanma gibi yüzeysel bir boyutta gerçekleşir.

\section{KAYNAKÇA:}

ANDREAS Huyssen, Postmodernin Haritasını Yapmak, (Çev. Mehmet Küçük), Modernite Versus Postmodernite içinde (Haz. Mehmet Küçük), Vadi Yayınları, Ankara, 1994

ARMAĞAN, Mustafa; Hilmi Yavuz ile Doğu'ya ve Batı'ya Yolculuk, Ufuk Kitapları, istanbul, 2003 BOYM, Svetlana; Nostaljinin Geleceği, Metis Yayınları, i̇stanbul, 2009

CüNDiOĞLU, Dücane; Mevlana, Şems ve Aşk, Yeni Şafak Gazetesi, 29.08. 2009, http://yenisafak.com.tr/yazarlar/:t=29.08.2009\&y=DucaneCundioglu

EKiZ, Tevfik, "Alımlama Estetiği mi Metinlerarasılık mı", Ankara Üniversitesi Dil ve TarihCoğrafya Fakültesi Dergisi 47, 2Ankara, 2007

FEATHERSTONE, Mike, Postmodernizm ve Tüketim Kültürü, (Çev: Mehmet Küçük), Ayrıntı Yayınları, ìstanbul, 2005

GiDDENS, Anthony; Modernliğin Sonuçları, Çev.: Ersin Kuşdil, Ayrıntı Yayınları, İstanbul, 2004

HOBSBAWM, Eric; Kısa 20. Yüzyıl "1914-1991 Aşırılıklar Çağı", Everest Yayınları, Çev.: Yavuz Alagon, İstanbul, 2006

HUTCHEON, Linda (1988). A Poetics of Postmodernism: History, Theory, Fiction, London, Routledge; (Alıntı Yapılan Kaynak: Öğretir, İsmail; (2009), "Dünyazatname: John Barth'ın Anlatı Irmaklarında Bir Gezinti", Çankaya Üniversitesi Fen-Edebiyat Fakültesi, Journal of Arts and Sciences Sayı: II / Mayıs 2009, Ankara)

KAHRAMAN, Hasan Bülent; Postmodernite ile Modernite Arasında Türkiye, Everest Yayınları, istanbul, 2007

KAHRAMAN, Hasan Bülent; "Beyazlar Kirli”, Agora Kitaplı̆̆, ístanbul, 2008

KIZILER, Funda; Moderniteden Postmoderniteye Kavramsal Bir Yolculuk, Salkım Söğüt Yayınları, Erzurum, 2006

OPPERMANN, Serpil; Postmodern Tarih Kuramı Tarihyazımı, Yeni Tarihselcilik ve Roman, Phoenix Yayınevi, Ankara, 2006

PAPPENHEIM, Fritz; Modern İnsanın Yabancılaşması, Çev.: Salih Ak, Phoenix Yayınevi, Ankara, 2002

STAUTH, Georg; Turner, Bryan S., "Nostalji, Postmodernizm ve Kitle Kültürü Eleştirisi, Çev.: Mehmet Küçük, Theory, Culture and Society, cilt: 5, No: 2/3, 1998

ŞAYLAN, Gencay; Postmodernizm, İmge Kitabevi, Ankara, 2009

WEST; David, Kıta Avrupası Felsefesine Giriş, (Çev. Ahmet Cevizci), Paradigma Yayınları, i̇stanbul, 2005

YAVUZ, Hilmi; Pamuk ve Nobel, Zaman Gazetesi, 29.06.2006, http:// www. zaman.c om.tr/ yazar.do?yazino=444653\&keyfield=6F7279616E74616C697A6D

YAVUZ, Hilmi, Anti Emperyalist Bir Soykütüğü, Zaman Gazetesi, 01. 07. 2012 http:/ /arsiv. zaman. com.tr//2001.06.01/yazarlar/HilmiYAVUZ.htm

YAVUZ, Hilmi; “Haşim, İntihal ve Metinleraraslık (2)", http:// arsiv. zaman. com.tr /2002. 05.01/ yazarlar/hilmiyavuz.htm 